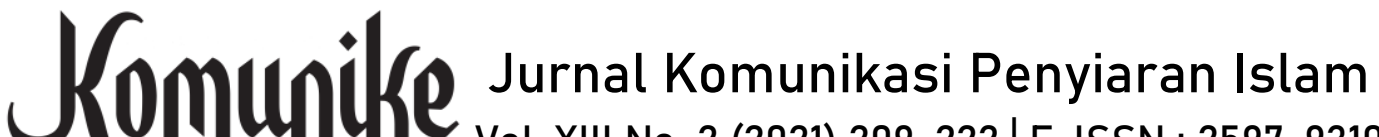 Vol. XIII No. 2 (2021) 209-222 | E-ISSN : 2597-9310
}

Submission : 17 - 11 - 2021 | Revisions : 30 - 12 - 2021| DOI: 10.20414/jurkom.v13i2.4214

\section{INTENSITAS PEMBERITAAN KEGIATAN KEAGAMAAN PADA SURAT KABAR POSMETRO ROHIL}

\author{
Heri Rahmatsyah Putra ${ }^{(1)}$ dan Fadhlur Rahman Armi \\ STAIN Teungku Dirundeng Meulaboh \\ ${ }^{(1)}$ herirahmatsyahputra@staindirundeng.ac.id
}

\begin{abstract}
The purpose of this study is to find out the intensity of the reports on Posmetro Rohil's newspaper on religious activities. It attracts the attention of the writer because Posmetro Rohil is a newspaper in the middle of Rokan Hilir's society which is mostly fanatical of religious activities. The method used in this research is a qualitative descriptive with data acquisition through observation, interview, and documentation. It is known from this study that the factor affecting the story of Posmetro Rohil is based on an individual factor that describes that media management personnel do not have a higher tendency towards religious activity. Then outside media factors like resource and media revenue. And the last ideological factor, Posmetro is an independent newspaper and does not bring interest to a particular group. Although news about religious activity is news that tends to attract interest in reading society.
\end{abstract}

Keyword: Intensity, News, Religious Activities, Posmetro Rohil

\begin{abstract}
Abstrak
Penelitian ini bertujuan untuk mengetahui intensitas pemberitaan pada surat kabar Posmetro Rohil terhadap kegiatan keagamaan. Hal ini menarik perhatian penulis karena Posmetro Rohil merupakan surat kabar yang hadir di tengah masyarakat Rokan Hilir yang mayoritasnya fanatik terhadap kegiatan keagamaan. Metode yang digunakan dalam penelitian ini ialah deskriptif kualitatif dengan perolehan data melalui observasi, wawancara, dan dokumentasi. Dari penelitian ini diketahui bahwa faktor yang mempengaruhi pemberitaan pada Posmetro Rohil didasarkan kepada faktor individual yang menggambarkan bahwa personil manajemen media tersebut tidak memiliki kecenderungan yang berlebih terhadap kegiatan keagmaan. Kemudian faktor luar media seperti narasumber dan penghasilan media. Dan yang terakhir faktor ideologi, Posmetro merupakan surat kabar yang independen dan tidak membawa kepentingan suatu kelompok tertentu. Walaupun berita mengenai kegiatan keagamaan memang berita yang cenderung dapat menarik minat membaca masyarakat.
\end{abstract}

Kata kunci : Intensitas, Pemberitaan, Kegiatan keagamaan, Posmetro Rohil

Lisensi

Creative Commons Attribution-NonCommercial 4.0 International License

Heri R. Putra dan Fadhlur R. Armi 209 


\section{A. PENDAHULUAN}

Media komunikasi saat ini mengalami perkembangan dari masa ke masa, salah satu penyempurnaan paling besar dari perkembangan komunikasi manusia adalah ditemukannya percetakan. Sebelum abad 15 manusia memproduksi buku-buku dengan mempersiapkan manuskripti/ manuskrip yang berupa salinan yang dicetak dengan menggunakan tangan. Hal penting yang mengikuti era perkembangan era cetak ini adalah penggunaan kertas sebagai bahan untuk merekam tulisan. Cetakan sebagaimana saat ini pada awalnya merupakan prakarsa seorang tukang emas berkebangsaan Jerman yang bernama Johan Gutenberg. Pada tahun $1455 \mathrm{M}$ ia memperkenalkan cara unik mencetak. Maka setelah itu tahun 1500 M percetakan telah didirikan di 250 tempat di Eropa, 80 diantaranya di Itali, 52 di Jerman, dan 43 di Perancis. ${ }^{1}$

Media cetak merupakan suatu media yang statis dan mengutamakan peran-peran visual. Media ini terdiri dari lembaran dengan sejumlah kata, gambar, atau foto, dalam tata warna dan halaman putih. Ada delapan jenis media cetak diantaranya surat kabar harian, surat

${ }^{1}$ Syukur Kholil, Teori Komunikasi Massa (Bandung: Citapustaka Media Perintis, 2011). h. 19 kabar mingguan, majalah mingguan, majalah tengah bulanan, majalah bulanan, majalah dwibulanan, majalah tribulanan, dan bulletin. Dari kedelapan media cetak tersebut Posmetro Rohil termasuk media cetak Harian, karena pada surat kabar Posmetro Rohil terbit setiap hari.

Posmetro Rohil adalah Semangat Baru Negeri Seribu Kubah, yang merupakan media cetak pertama kali berdiri di Kabupaten Rokan Hilir. Posmetro Rohil mengutamakan berita lokal demi kepentingan informasi aktual yang akan diperoleh masyarakat Kabupaten Rohil khususnya Bagansiapiapi. $^{2}$

Demi memperoleh kelancaran informasi Posmetro memiliki beberapa jurnalis yang profesional, namun Posmetro Rohil memiliki kekurangan dari sudut pandang penulis. Adapun sudut pandang yang kurang dari penulis yaitu kurangnya berita kegiatan keagamaan yang diperoleh masyarakat Kabupaten Rokan Hilir. Dengan kurangnya berita kegiatan keagamaan ini penulis berharap kepada Posmetro Rohil untuk masa yang akan datang tentang berita kegiatan keagamaan bisa menjadi sajian masyarakat Kabupaten Rokan

\footnotetext{
${ }^{2}$ Posmetro Rohil, Semangat Baru Negeri Seribu Kubah : 2014, h. 6
} 
Hilir sebagai berita harian, sesuai dengan gelar Kabupaten Rokan Hilir dengan sebutan sebagai "Negeri Seribu Kubah". Dengan sebutan ini Posmetro Rohil harus bersusah payah untuk mengembangkan atau memberi informasi kepada masyarakat tentang berita kegiatan keagamaan.

Kegiatan keagamaan adalah segala perbuatan, perkataan, lahir bathin seseorang atau individu yang didasarkan pada nilai-nilai atau norma-norma yang berpangkal pada ajaran-ajaran agama, yang telah menjadi kebiasaan hidup sehari-hari. Kegiatan keagamaan memfokus untuk informasi suatu agama, pada penelitian ini difokuskan tentang islam kepada masyarakat luas khususnya di Kabupaten Rokan Hilir yang menyangkut kepada setiap kerohanian seseorang. Berdasarkan asumsi dan pemikiran di atas maka penulis merasa tertarik untuk mengadakan suatu penelitian tentang intensitas pemberitaan kegiatan agama pada surat kabar Posmetro Rohil. Penelitian ini bertujuan untuk mengetahui seberapa banyak berita mengenai kegiatan keagamaan yang dimuat pada harian Posmetro Rohil.

\section{B. LITERATURE REVIEW}

\section{Media Cetak}

Media cetak adalah suatu media yang statis dan mengutamakan peranperan visual. Media ini terdiri dari lembaran dengan sejumlah kata, gambar, atau foto dalam tata warna dan halaman putih. $^{3}$

Seperti Televisi dan Radio dalam jajaran medium penyiaran. Fungsi utama media cetak adalah memberi informasi dan menghibur. Media cetak adalah suatu dokumen atas segala hal yang dikatakan orang lain dan rekaman peristiwa yang ditangkap oleh sang jurnalis dan diubah dalam bentuk katakata, gambar, foto dan sebagainya. Orang-orang yang bekerja pada media cetak memperoleh penghargaan jurnalistik yang dihormati karena kredibilitasnya.

Kata koran berasal dari bahasa Belanda krant dan bahasa Prancis courant. Surat kabar adalah lembaranlembaran kertas bertuliskan berita berbagai topik. Surat kabar berdasarkan ruang lingkupnya dapat dibagi menjadi surat kabar Nasional, Regional dan Lokal. Ada pula surat kabar yang berbentuk surat kabar biasa dan tabloid.

\footnotetext{
${ }^{3}$ www. Anneahira.com Pengertian Media Cetak dan jenisnya, diakses pada tanggal 15 September 2016
}

Heri R. Putra dan Fadhlur R. Armi 211 
Cara penyajian surat kabar yang ada yang disajikan dalam bentuk bahasa Indonesia, bahasa Inggris dan bahasa Daerah. $^{4}$

Karakteristik surat kabar, antara lain bersifat publisitas atau bersifat penyebaran pesan kepada publik, periodik atau keteraturan terbit dan universalitas atau menyampaikan pesan yang beragam dapat diakses secara umum. Surat kabar juga mempunyai sifat aktualitas atau kini, yaitu baru saja terjadi atau sedang terjadi. Setiap media bersifat relatif karena tergantung pada periode media tersebut, misalnya surat kabar pagi dan surat kabar sore, terdokumentasi dan dapat diarsip, serta faktual atau sesuai dengan fakta. Namun, surat kabar memiliki kelemahan, yaitu informasi yang disajikan tidak mendalam.

Surat kabar minimal memiliki empat posisi, yaitu sebagai lembaga sosial, lembaga ekonomi, produk informasi dan media informasi. sebagai media informasi, surat kabar perlu mengikuti perkembangan teknologi komunikasi. Dengan demikian, surat kabar dapat meningkatkan pelayanannya bagi pembaca.

\footnotetext{
${ }^{4}$ Irmas Sari, Berkomunikasi (Yogyakarta: KTSP, 2010). h.62
}

2. Jenis-jenis media cetak

Secara umum, Jenis media cetak yang ada di Indonesia diklasifikasikan menjadi delapan bagian. Pengklasifikasikan tersebut, didasarkan pada waktu terbit media tersebut. Hal ini sesuai dengan apa yang dikeluarkan oleh Dirjen pembinaan Pers dan Grafika, tentang media cetak dan pengklasifikasianya. Kedelapan jenis media cetak tersebut diantaranya adalah sebagai berikut :

a) Surat kabar harian Adalah jenis media cetak yang terbit setiap hari, kecuali pada hari-hari tertentu, seperti pada libur nasional jenis media cetak ini masih dibagi lagi menjadi surat kabar Harian Nasional, surat kabar Harian Daerah dan surat kabar Harian Lokal. Berita yang disampaikan adalah jenis berita News atau informasi terkini dan disampaikan dengan sistem straight News atau apa adanya.

b) Surat Kabar Mingguan. Jenis media cetak ini lebih banyak dikenal dengan sebutan tabloid. Biasanya berita yang diangkat adalah berita hiburan atau juga in depth news atau liputan mendalam. Tulisan dalam media ini lebih banyak bergaya feature atau deskriptif.

c) Majalah Mingguan. Jenis majalah ini terbit setiap minggu sekali. Yang 
diangkat adalah berita in depth News dengan jenis berita adalah berita News atau tentang sebuah peristiwa.

d) Majalah Tengah Bulanan. Majalah ini terbit setiap sebulan dua kali. Berita yang ditampilkan lebih bersifat informative dan biasanya memuat tentang berita Life Style.

e) Majalah Bulanan. Majalah bulanan terbit sekali dalam sebulan. Jenis pemberitaan yang disampaikan biasanya termasuk investigatif atau berita yang dapat dari hasil penelitian.

f) Majalah Dwibulanan. Majalah ini terbit sekali dalam dua bulan. Informasi yang disampaikan dalam majalah ini biasanya terkait dengan laporan dari hasil aktivitas sesuatu. Misalnya, laporan neraca perusahaan atau juga majalah yang berisi laporan pendapatan sebuah lembaga zakat.

g) Majalah Tribulanan. Majalah ini berkonsep hampir mirip dengan majalah dwibulanan. Yang membedakan hanya masalah waktu terbit, yang dilakukan setiap tiga bulan sekali.

h) Bulletin. Majalah ini biasanya dibuat untuk kalangan tertentu atau interen saja. Dan, media ini biasanya terdiri dari beberapa halaman, serta dibuat dengan konsep sederhana. Bulletin dibuat juga tidak dibuat untuk kepentingan komersial.

Jenis media tersebut mempunyai berbagai macam bidangnya lagi. Seperti yang sudah dijelaskan di atas, jenis media cetak tersebut dibagi lagi berdasarkan usia, informasi dan bidangnya. Jadi, perusahaan media cetak yang ada di Indonesia sudah banyak jenisnya. $^{5}$

3. Kelebihan \& kekurangan media cetak

a) Kelebihan Media Cetak

1) Repeatable, dapat di baca berkalikali dengan menyimpannya atau mengklipingnya.

2) Analisa lebih tajam, dapat membuat orang benar-benar mengerti isi berita dengan analisa yang lebih mendalam dan dapat membuat orang berfikir lebih spesifik tentang isi tulisan.

\section{b) Kekurangan Media Cetak}

1) Lambat, dari segi waktu media cetak adalah yang terlambat karena media cetak tidak dapat menyebarkan langsung berita yang terjadi kepada masyarakat dan harus menunggu turun cetak. Media cetak sering kali hanya memuat berita yang telah disebarluaskan oleh media lainnya.

5 Toto Djuroto, Manajemen Penerbitan Pers (Bandung: Remaja Rosdakarya, 2004).

Heri R. Putra dan Fadhlur R. Armi 213 
2) Tidak adanya audio, media cetak hanya berupa tulisan yang tentu saja tidak dapat didengar.

3) Visual yang terbatas, media cetak hanya dapat memberikan visual berupa gambar yang mewakili keseluruhan isi berita.

4) Produksi, biaya produksi yang cukup mahal karena media cetak harus mencetak dan mengirimkannya sebelum dapat dinikmati masyarakat. ${ }^{6}$

4. Faktor yang mempengaruhi isi media Apa yang disajikan media, pada dasarnya adalah akumulasi dari pengaruh yang beragam. Pamela J. Shoemaker dan Stephen D. Reese, dalam Mediating The Message: Theories of Influences on Mass Media Content, menyusun berbagai faktor yang mempengaruhi pengambilan keputusan dalam ruang pemberitaan. Mereka mengidentifikasikan ada lima faktor yang mempengaruhi kebijakan redaksi dalam menentukan isi media, sebagai berikut: $^{7}$

a) Faktor individual. Faktor ini berhubungan dengan latar belakang profesional dari pengelola media. Level indivual melihat bagaimana

6 Toto Djuroto, Manajemen Penerbitan Pers (Bandung: Remaja Rosdakarya, 2004)

${ }^{7}$ McQuail, Teori Komunikasi Massa, 2nd edn (Jakarta: Erlangga, 1987). pengaruh aspek-aspek personal dari pengelola media mempengaruhi pemberitaan yang akan ditampilkan kepada khalayak.

b) Rutinitas media, berhubungan dengan mekanisme dan proses penentuan berita. Setiap media umumnya mempunyai ukuran sendiri tentang apa yang disebut berita, apa ciri-ciri berita yang baik, atau apa kriteria kelayakan berita. Ukuran tersebut adalah rutinitas yang berlangsung tiap hari dan menjadi prosedur standar bagi pengelola media yang berada di dalamnya. Rutinitas media ini juga berhubungan dengan mekanisme bagaimana berita dibentuk.

c) Organisasi. Level organisasi berhubungan dengan struktur organisasi yang secara hipotetik mempengaruhi pemberitaan. Pengelola media dan wartawan bukan orang tunggal yang ada dalam organisasi berita, ia sebaliknya hanya bagian kecil dari organisasi media itu. Masing-masing komponen dalam organisasi media bisa jadi mempunyai kepentingan sendiri-sendiri. Di dalam organisasi media, misalnya, selain bagian redaksi ada juga bagian pemasaran, bagian iklan, bagian sirkulasi, bagian umum, dan seterusnya. Masing-masing bagian 
tersebut tidak selalu sejalan. Mereka mempunyai tujuan dan target masingmasing, sekaligus strategi yang berbeda untuk mewujudkan target tersebut. Bagian redaksi misalnya menginginkan agar berita tertentu yang disajikan, tetapi bagian sirkulasi menginginkan agar berita lain yang ditonjolkan karena terbukti dapat menaikkan penjualan. Setiap organisasi berita, selain mempunyai banyak elemen juga mempunyai tujuan dan filosofi organisasi sendiri, berbagai elemen tersebut mempengaruhi bagaimana seharusnya wartawan bersikap, dan bagaimana juga seharusnya peristiwa disajikan dalam berita.

d) Ekstra media. Level ini berhubungan dengan faktor lingkungan di luar media. Meskipun berada di luar organisasi media, hal-hal di luar organisasi media ini sedikit banyak dalam banyak kasus mempengaruhi pemberitaan media. Ada beberapa faktor yang termasuk dalam lingkungan di luar media:

1) Sumber berita. Sumber berita di sini dipandang bukanlah sebagai pihak yang netral yang memberikan informasi apa adanya, ia juga mempunyai kepentingan untuk mempengaruhi media dengan berbagai alasan: memenangkan opini publik, atau memberi citra tertentu kepada khalayak, dan seterusnya. Sebagai pihak yang mempunyai kepentingan, sumber berita tentu memberlakukan politik pemberitaan. Ia akan memberikan informasi yang sekiranya baik bagi dirinya, dan mengembargo informasi yang tidak baik bagi dirinya. Kepentingan sumber berita ini sering kali tidak disadari oleh media.

2) Sumber penghasilan media, berupa iklan, bisa juga berupa pelanggan/pembeli media. Media harus survive, dan untuk bertahan hidup kadangkala media harus berkompromi dengan sumber daya yang menghidupi mereka. Misalnya media tertentu tidak memberitakan kasus tertentu yang berhubungan dengan pengiklan. Pihak pengiklan juga mempunyai strategi untuk memaksakan versinya pada media. Ia tentu saja ingin kepentingannya dipenuhi, itu dilakukan di antaranya dengan cara memaksa media mengembargo berita yang buruk bagi mereka. Pelanggan dalam banyak hal juga ikut mewarnai pemberitaan media. 
Tema tertentu yang menarik dan terbukti mendongkrak penjualan, akan terus-menerus diliput oleh media. Media tidak akan menyianyiakan momentum peristiwa yang disenangi oleh khalayak.

3) Pihak eksternal seperti pemerintah dan lingkungan bisnis. Pengaruh ini sangat ditentukan oleh corak dari masing-masing lingkungan eksternal media. Dalam negara yang otoriter misalnya, pengaruh pemerintah menjadi faktor yang dominan dalam menentukan berita apa yang disajikan. Keadaan ini tentu saja berbeda di negara yang demokratis dan menganut liberalisme. Campur tangan negara praktis tidak ada, justru pengaruh yang besar terletak pada lingkungan pasar dan bisnis.

e) Ideologi, diartikan sebagai kerangka berpikir atau kerangka referensi tertentu yang dipakai oleh individu untuk melihat realitas dan bagaimana mereka menghadapinya. Berbeda dengan elemen sebelumnya yang tampak konkret, level ideologi ini abstrak. Ia berhubungan dengan konsepsi atau posisi seseorang dalam menafsirkan realitas. ${ }^{8}$

\footnotetext{
${ }^{8}$ Eriyanto, Analisis Wacana: Pengantar Analisis Teks Media (Yogyakarta: LKis, 2001).
}

Raymond William mengklasifikasikan penggunaan ideologi tersebut kepada ${ }^{9}$

1) Sebuah sistem kepercayaan yang dimiliki oleh kelompok atau kelas tertentu. Definisi ini terutama dipakai oleh kalangan psikologi yang melihat ideologi sebagai seperangkat sikap yang dibentuk dan diorganisasikan dalam bentuk yang koheren. Sebagai misal, seseorang mungkin mempunyai seperangkat sikap tertentu mengenai demontrasi buruh. Ia percaya bahwa buruh yang berdemontrasi mengganggu kelangsungan produksi. Oleh karenanya, demontrasi tidak boleh ada, karena hanya akan menyusahkan orang lain, membuat keresahan, menggangu kemacetan lalulintas, dan membuat persahaan mengalami kerugian besar. Jika bisa memprediksikan sikap seseorang semacam itu, kita dapat mengatakan bahwa orang itu mempunyai ideologi kapitalis atau borjuis. Meskipun ideologi disini terlihat sebagai sikap seseorang, tetapi ideologi di sini tidak dipahami sebagai sesuatu yang ada dalam diri individu sendiri, melainkan diterima dari masyarakat.

\footnotetext{
${ }^{9}$ Ibid.
} 
2) Sebuah sistem kepercayaan yang dibuat ide palsu atau kesadaran palsu yang biasa dilawankan dengan pengetahuan ilmiah. Ideologi dalam pengertian ini adalah seperangkat kategori yang dibuat dan kesadaran palsu dimana kelompok yang berkuasa atau dominan menggunakannyauntuk mendominasi kelompok lain. Karena kelompok yang dominan mengontrol kelompok lain dengan menggunakan perangkat ideologi yang disebarkan ke dalam masyarakat, akan membuat kelompok yang didominasi melihat hubungan itu nampak natural, dan diterima sebagai kebenaran. Di sini, ideologi disebarkan lewat berbagai instrumen dari pendidikan, politik sampai media massa.

\section{Kegiatan Keagamaan}

Kata keagamaan merupakan istilah yang mengalami imbuhan dari kata dasar 'agama' dengan pengertian sebagai berikut agama adalah teks atau kitab suci yang mengandung ajaran-ajara yang menjadi tuntutan hidup bagi para penganutnya. $^{10}$ Pada pengertian lain agama adalah dustur atau Undangundang ilahi yang didatangkan Allah untuk menjadi pedoman hidup dalam

\footnotetext{
${ }^{10}$ Harun Nasution, Islam Ditinjau Dari Berbagai Aspek, 1st edn (Jakarta: UI Press, 1979). h.9
}

kehidupan di alam dunia untuk mencapai kebahagiaan akhirat. ${ }^{11}$ Sedangkan dalam KBBI, kata agama berarti suatu system, prinsip kepercayaan terhadap Tuhan dengan ajaran kebaktian dan kewajibankewajiban yang bertalian dengan kepercayaan itu. ${ }^{12}$ Dengan definisi di atas dapat disimpulkan bahwa agama adalah peraturan tuhan yang diberikan kepada manusia, untuk mencapai kebahagiaan hidup di dunia dan di akhirat kelak.

Dari pengertian di atas penulis dapat membuat penilaian bahwa yang dimaksud dengan kegiatan keagamaan adalah segala perbuatan, perkataan, lahir batin seseorang atau individu yang didasarkan pada nilai-nilai atau normanorma yang berpangkal pada ajaranajaran agama, yang telah menjadi kebiasaan hidup sehari-hari. Maka tujuan yang hendak dicapai dari kegiatan keagamaan adalah:

a) Meningkatkan intensitas dakwah islamiyah kepada khalayak dalam rangka membangun khalayak generasi terdepan yang relegius, sebagai implementasi islam adalah rahmatan lil'alamin.

\footnotetext{
11 Muhaimin, Problematika Agama Dalam Kehidupan Manusia (Jakarta: Kalam Mulia, 1989). h.139

12 Lotus Life, (online) http://sujatanet.blogspot.com/2009/01/pengertianagama.html. Diakses tanggal 11 juni 2016
}

Heri R. Putra dan Fadhlur R. Armi 217 
b) Membangun kesadaran khalayak bahwa kegiatan keagamaan akan memotivasi sikap beragama yang baik dan kontinue.

c) Membangun pribadi khalayak yang terbiasa dalam melaksanakan ibadah.

d) Menciptkan generasi dengan tingkat kecerdasan spiritual (SQ) yang baik, sehingga melahirka generasi yang menjunjung tinggi etika, moral dan nilai-nilai religius.

e) Meningkatkan kemampuan masyarakat, beraspek kognitif. afektif. Dan psikomotorik.

f) Mengembangkan bakat dan minat masyarakat dalam upaya pembinaan pribadi menuju pembinaan manusia seutuhnya yang positif.

6. Kajian Penelitian Yang Relevan

Dari kajian pustaka yang telah dilakukan, ada beberapa penelitian yang relevan yang telah ditemukan oleh peneliti-peneliti terdahulu, di antaranya adalah:

a) Penelitian yang dilakukan oleh $\mathrm{M}$. Taufan, B. (STAIN Datokarama Palu, 2013), dengan judul "Pengaruh Pemberitaan Surat Kabar Terhadap Prasangka Agama di Kota Palu". Fokus penelitian ini yaitu, sebagai General Chek Up kehidupan dalam kehidupan dan kerukunan antar agama, khususnya toleransi, hormat menghormati, dan tolong menolong antar pemeluk agama lainnya. Yang tentunya akan merugikan salah satu pihak penganut ataupun pemeluk agama lainnya. Dengan demikian di dalam pokok penelitian ini adalah : "seberapa besar pengaruh pemberitaan media cetak tentang prasangka agama dan kelompok pergaulan terhadap sikap pada prasangka agama". ${ }^{13}$

Dari kesimpulan tersebut jelas terdapat perbedaan dan kesamaannya dengan penelitian penulis. Perbedaannya adalah prasangka agama, sedangkan penelitian penulis tentang kurangnya berita keagamaan dan tahun penelitian penulis sekarang adalah tahun 2019, sedangkan persamaannya adalah pengaruh berita keagamaan pada suatu surat kabar.

b) Penelitian yang dilakukan oleh Khairul Amri, SE, M. Si (Akademi Sekretariat dan Manajemen (ASM) Nusantara Banda Aceh, 2012), dengan judul "Faktor-faktor yang Mempengaruhi Loyalitas Konsumen Surat Kabar Harian Serambi Indonesia di Kota Banda Aceh".

\footnotetext{
13 Taufan, M. B. "Pengaruh pemberitaan surat kabar terhadap prasangka agama di Kota Palu (Suatu Kajian Sosiologi Hukum Islam)." ISTIQRA', Jurnal Penelitian Ilmiah P3M STAIN Datokarama Palu 1.1 (2013): 23-57.
} 
Dengan fokus penelitian untuk mengetahui faktor-faktor tersebut berpengaruh terhadap Loyalitas pelanggan surat kabar harian serambi Indonesia di kota Banda Aceh. Responden penelitian adalah sebanyak 85 orang pelanggan, surat kabar tersebut di ambil secara purposive sampling. Pengumpulan data dilakukan dengan mengedarkan kuesioner yang berisi pernyataanpernyataan yang berhubungan dengan 17 faktor yang di duga membentuk perilaku pelanggan surat kabar, serta loyalitas pelanggan sebagai Dependent Variabel. ${ }^{14}$

Adapun hasil penelitian ini dapat disimpulkan bahwa factor-faktor yang mempengaruhi loyalitas konsumen surat kabar harian serambi Indonesia di kota Banda Aceh. Dari kesimpulan tersebut jelas perbedaan dengan penelitian penulis yang berfokus terhadap factorfaktor yang mempengaruhi kurangnya berita keagamaan pada surat kabar Posmetro Rohil.

Berdasarkan studi kepustakaan di atas, tidak ditemukan penelitian yang membahas sesuai dengan sasaran kajian

\footnotetext{
${ }^{14}$ Amri, Khairul. "Faktor-faktor yang mempengaruhi loyalitas konsumen surat kabar Harian Serambi Indonesia di kota Banda Aceh." Jurnal Ekonomi Manajemen dan Bisnis 1.1 (2013): 229-242.
}

penulis, karena itu penelitian ini menurut penulis sangat perlu dilakukan, agar mendapat gambaran yang jelas dan fokus tentang masalah tersebut dan dalam rangka membuka pemikiran yang baru, khususnya mengenai pengaruh kurangnya berita keagamaan.

\section{METODE PENELITIAN}

Dalam penelitian ini menggunakan pendekatan penelitian kualitatif. Penelitian kualitatif bertujuan menjelaskan suatu fenomena menurut spektif penulis yang tidak dapat dinyatakan atau diuji dengan bilangan (angka). ${ }^{15}$

Penelitian kualitatif ini mendeskripsikan segala sesuatu yang berkaitan dengan faktor-faktor yang mempengaruhi kurangnya kegiatan keagamaan pada surat kabar posmetro Rohil. Penelitian kualitatif jauh lebih subjektif dari pada penelitian atau survei kuantitatif dan menggunakan metode sangat berbeda dari mengumpulkan informasi, terutama individu, dalam menggunakan wawancara secara mendalam dan grup fokus.

Metode kualitatif mengambil kesimpulan berdasarkan jenis data yang

\footnotetext{
${ }^{15}$ Hidayat Syah, Metodologi Penelitian Pendidikan Pendekatan Verifikative (Pekanbaru: SUSKA Perss, 2010).
} 
tidak dapat diukur secara langsung atau lebih tepatnya tidak dapat dihitung dari data yang didapatkan kemudian ditarik kesimpulan. ${ }^{16}$

Teknik pengumpulan data merupakan salah satu metode atau cara yang dilakukan penulis untuk memperoleh keterangan yang benar dan dapat dipertanggung jawabkan. Dalam penelitian ini teknik pengumpulan data dan informasi yang digunakan adalah teknik pengumpulan data Kualitatif menggunakan Observasi, Wawancara dan Dokumentasi.

\section{HASIL DAN PEMBAHASAN}

Berdasarkan penelitian yang dilakukan menunjukkan bahwa faktorfaktor yang menentukan isi pemberitaan pada harian Posmetro Rohil ialah faktor individual, Individu atau personil pada manajemen redaksi Posmetro Rohil cenderung lebih tertarik untuk tidak bersifat fanatik atau kecenderungan berlebih terhadap pemberitaan mengenai kegiatan keagamaan.

Hal ini dikarenakan sebuah media cetak harus bersifat menaungi seluruh kelompok masyarakat. Posmetro Rohil merupakan harian surat kabar yang bersifat umum, tentu saja porsi berita

16 Sugiono, Metode Penelitian Administrasi (Bandung: Alfabeta, 2009). h.14 yang dimuat harus sesuai dan merata terhadap seluruh aspek kehidupan masyarakat.

Selain itu rutinitas media, sudah selayaknya sebuah media akan menyajikan berita yang factual dan actual. Berita yang dirasa penting dan lebih penting akan lebih dipriotaskan untuk menarik minat pembaca dan memenuhi kebutuhan masyarakat terhadap berita-berita yang penting dan lebih hangat untuk dikonsumsi.

Hal ini tidak menutup kemungkinan untuk memuat beritaberita mengenai kegiatan keagamaan. Jika pemberitaan yang dimuat tidak bersifat variatif maka tentu pembaca akan merasa bosan dan tidak tertarik terhadap surat kabar Posmetro Rohil. Karena pasti akan memunculkan paradigm media tersebut memiliki kepentingan sebuah kelompok dan tidak independen. Hal ini sesuai dengan yang disampaikan oleh Direktur Posmetro Rohil, ia mengatakan ketika ada sebuah peristiwa penting yang harus diliput, bagaimana bentuk pendelegasian tugasnya, melelui proses dan tangan siapa saja tulisa sebelumnya sampai proses cetak, siapa penulisnya, siapa editornya, dan seterusnya.

Menurut wartawan Posmetro Rohil, ia mengatakan proses penentuan 
berita dibentuk dialah ketika ada sebuah berita penting yang harus diliput sehingga akan bias menjadi sebuah pemberitaan actual melalui seorang penulis, editor dan sampai proses pencetakan".

Namun faktor yang paling berpengaruh dalam pemberitaan pada harian Posmetro Rohil ialah faktor ekstra media atau luar media. Berita yang diperoleh dari narasumber umumya memiliki nilai kepentingan, bagaimana seorang narasumber dalam memberikan berita kepada wartawan Posmetro Rohil akan menitik beratkan kepada informasi yang terkesan baik-baik saja untuk mempengaruhi pembaca dalam hal ini masyarakat.

Kemudian unsur penghasilan media, konten iklan yang dimuat pada harian Posmetro Rohil cenderung mendominasi isi dari harian tersebut. Hal ini dimaklumi karena surat kabar tidak akan bertahan lama tanpa pemasukan dari iklan yang dimuat. Kepercayaan para pembaca tidak akan cukup untuk membuat sebuah surat kabar bertahan apabila tidak ditopang dengan keuangan manajemen yang kuat. Hal ini dikarenakan Posmetro Rohil merupakan harian surat kabar yang bersifat independen tanpa adanya intervensi dari pemerintah. Begitu pula dengan lembaga atau organisasi keagamaan.

Sehingga seluruh rutinitas pemberitaan dilaksanakan berdasarkan ideologi dan prinsip manajemen redaksi tersebut. Masyarakat Rokan Hilir yang dominan bersuku Melayu memang cenderung fanatik terhadap kegiatankegiatan keagamaan, sehingga berita yang diperoleh tentu akan lebih banyak menyangkut kegiatan kemasyarakatan yang cenderung dekat dengan nilai-nilai agama. Hal ini pula yang menjadikan dianggap penting dan lebih menarik apabila pemberitaan pada harian surat kabar Posmetro Rohil cenderung lebih banyak diisi dengan kegiatan-kegiatan keagamaan.

\section{E. KESIMPULAN}

Posmetro Rohil merupakan media cetak yang selalu mengutamakan publikasi informasi lokal yang actual dan terlengkap, adapun faktor-faktor yang mempengaruhi intensitas pemberitaan kegiatan keagamaan pada harian Posmetro Rohil dikarenakan berita kegiatan keagamaan bisa menjadi nilai jual bagi Posmetro Rohil terhadap masyarakat, karena dengan terbitnya berita kegiatan keagamaan setiap harinya bisa menambah pembaca atau pelanggan baru yang suka terhadap 
berita keagamaan tersebut. Posmetro

Rohil akan selalu memberikan berita kegiatan keagamaan yang aktual dan terpercaya kepada masyarakat Rohil dalam penginformasiannya, sehingga Posmetro Rohil akan selalu menjadi dambaan bagi pelanggan dalam daerah dan luar daerah.

\section{F. DAFTAR PUSTAKA}

Amri, Khairul. "Faktor-faktor yang mempengaruhi loyalitas konsumen surat kabar Harian Serambi Indonesia di kota Banda Aceh." Jurnal Ekonomi Manajemen dan Bisnis 1.1 (2013): 229-242

Djuroto, Toto, Manajemen Penerbitan Pers (Bandung: Remaja Rosdakarya, 2004)

Eriyanto, Analisis Wacana: Pengantar Analisis Teks Media (Yogyakarta: LKis, 2001)

Kholil, Syukur, Teori Komunikasi Massa (Bandung: Citapustaka Media Perintis, 2011)

Lotus Life, (online) http://sujatanet.blogspot.com/2009/01/pengerti an-agama.html. Diakses tanggal 11 juni 2016

McQuail, Teori Komunikasi Massa, 2nd edn (Jakarta: Erlangga, 1987) Muhaimin, Problematika Agama Dalam
Kehidupan Manusia (Jakarta:

Kalam Mulia, 1989)

Nasution, Harun, Islam Ditinjau Dari Berbagai Aspek, 1st edn (Jakarta: UI Press, 1979)

Posmetro Rohil, Semangat Baru Negeri Seribu Kubah : 2014

Sari, Irmas, Berkomunikasi (Yogyakarta: KTSP, 2010)

Sugiono, Metode Penelitian Administrasi (Bandung: Alfabeta, 2009)

Syah, Hidayat, Metodologi Penelitian Pendidikan Pendekatan Verifikative (Pekanbaru: SUSKA Perss, 2010)

Taufan, M. B. "Pengaruh pemberitaan surat kabar terhadap prasangka agama di Kota Palu (Suatu Kajian Sosiologi Hukum Islam)." ISTIQRA', Jurnal Penelitian Ilmiah P3M STAIN Datokarama Palu 1.1 (2013): 2357.

www. Anneahira.com Pengertian Media Cetak dan jenisnya, diakses pada tanggal 15 September 2016 